\title{
Signs of Anger: Representation of Agonistic Behaviour in Invertebrate Cognition
}

\section{Stephen Philip Pain}

Received: 17 September 2008 / Accepted: 12 January 2009 /

Published online: 20 May 2009

(C) Springer Science + Business Media B.V. 2009

\begin{abstract}
In this essay I shall examine the representation of aggression and its issues in the model animal, the Fruit Fly, Drosophila melanogaster. The Fruit Fly is the model animal for genetics and more recently neuroscience. On the basis of its behaviour conclusions are being drawn that will help in the development of new treatments for clinical entities like aggression and anxiety disorders - the author questions those findings and asks whether more should be done to focus on the actual biology and behaviour - the Umwelt, instead of trying to bridge the gulf between invertebrate and human behaviours.
\end{abstract}

Keywords Aggression - Agonistic behaviour - Invertebrates · Representation · Umwelt

\section{The Adaptive Behaviours}

The behaviours of animals since 1956 have been traditionally catalogued as follows.

We can see that three adaptive behaviours are at work when a male fruit fly approaches another as in the aggression experiments. There is a blurring and a difficulty in finding out when one behaviour ends. Figures 1 and 2.

The chief rule for any good scheme of classification is that it should be natural and conform to discontinuity which exists in nature and which can be recognized by independent observers. The scheme of classification should be logical, and one that includes all related phenomena.

(Scott 1956, p.214)

When observing the behaviour of thousands of interactions, one has to decide quite what it is that you are interested in. This is achieved through cataloguing a

S. P. Pain $(\bowtie)$

Kongensgade, 15 1-sal, 5000 Odense C, Denmark

e-mail: biorhetorics@mail.dk 


\begin{tabular}{|l|l|l|l|l|l|l|l|l|}
\hline Contractual & Ingestive & Eliminative & Sexual & Epimeletic & Etepimeletic & Agonistic & $\begin{array}{l}\text { Allelo } \\
\text { mimetic }\end{array}$ & Investigative \\
\hline
\end{tabular}

Fig. 1 Classification of adaptive behaviour (Scott 1956, p. 215)

specific behaviour (i.e. one behaviour of the animal's repertoire). From this one can create an ethogram. Watching fruit flies on the videos produced by the various laboratories, I realised just how difficult a task this is to do. It is very difficult to distinguish exactly when a fly is being agonistic in its nature. Indeed there are several overlaps in the units of three adaptive behaviours, namely, the ingestive or feeding, sexual or reproductive and the agonistic or aggressive. The isolation of distinct behaviours is exacerbated by the experiment's set up which included two very important attractants that are stimuli for two behaviours. These are sexual attractants (sex pheromones) emanating from decapitated female fruit flies, and the food mix used to attract them.

\section{The Distinction between Agonistic behaviour and Aggression}

An animal in an agonistic encounter is not necessarily aggressive. Much of this behaviour involves non contact outputs such as grooming, signalling, flight, and so on. The actual aggressive acts are limited. Aggression is a component of agonistic behaviour.

\section{The Units of an Ethogram should be Parsimonious}

In the fruit fly agonistic ethogram, the researchers since 1915 have described the movements using martial terms drawn from fencing and boxing. (Sturtevant 1915) While these are descriptive they tend also to suggest a homology with human aggressive acts that involve higher cognitive operations. This is not just a matter of semantics, as many experiments are conducted with the explicit object of discovering expression and connections of genes associated with agonistic behaviour in the fly so that similar biological components can be located in the human genome and systems. Tables 1 and 2

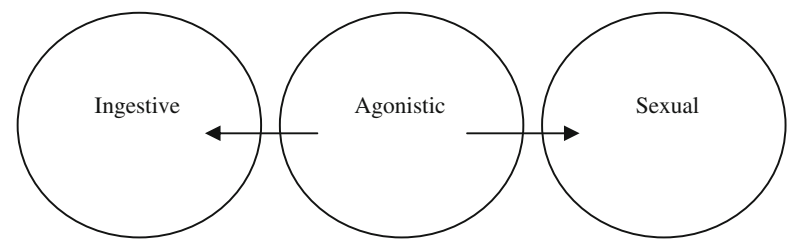

Fig. 2 Behaviour relations 


\section{Check the Modalities}

From research on the cross-modality of olfactory and visual systems we can know that an odorant can override the visual circuitry in the navigation programmewe have conflicting triggers that belong to two different adaptive behaviours. (Guo and Guo 2005). Doesn't the "noise" of the female's presence contaminate the findings? Isn't it also conceivable that when she is killed that like other insects alarm pheromones and necromones are produced? Perhaps not as according to one article the male flies sometimes tried to copulate with her. (Chen et al. 2002) Nevertheless, we could given the putative pheromones so far discovered hypothesise that in the agonistic zone there might be the following additional types of pheromones: (Source www.flybase, Ferveur 2007).

\section{The Analysis of One Component of the Fruit Fly Agonistic Algorithm. "The Wing Threat"}

Interestingly the units of behaviour observed in male-male aggression are also seen in the fruit fly courtship ethogram, though with significant mechanical differences. (Ejima and Griffith 2007, p. 4847, Spieth 1974, 387-388) For example in the agonistic behaviour algorithm, the wing threat is simply the movement of the wings to a 45 degree position, which constitutes a threat display, whereas in the case of the courtship behaviour, the male fly will vibrate its wings so as to send an acoustic signal of fitness to the female, the so-called "Drosophila love song". (Ejima, ibid; Chen ibid.) A comparison of these two movements is useful in identifying underlying problems in the approaches of neuroscience researchers. The wing threat is viewed as a visual form of communication, "cue", whereas the wing vibration is seen as more complex in cognitive terms. But is this the case? Are both wing movements not variations on the preparation for flight mode? In this case the mechanical movement in a wing threat might be just a transition reflex between flight and fight, and not a visual cue. Another explanation is suggested by the chemical communication system of arthropods. The wings of a fruit fly have hydrocarbons that constitute pheromones. It might be conceivable that the function of the wing threat is to actually extend the surface of inter-fly communication. The same is true of the wing vibration which could be used to fan pheromones.

\section{The Neurotransmission Systems}

In the agonistic encounter we can hypothesise that the systems involved are the following.

- Flight-related /focus (norepinephrine -type)

- Food -related (olfactory 1)

- Sex-related (pheromone 1)

- Modulatory (serotonin-type)

- Reward-related/focus attention (dopamine/opioid-type)

- Fear/panic-related (serotonin-type) 
What we cannot know is how these systems interact. They are not strictly structural or circuits, but complex biochemical processes. Furthermore they do not function in isolation from the body but must be linked to homeostatic systems. (Paulus 2007) ( On top of this we must in put factors such as learning, experience, memory, state of development, gender, and so on. Research is often monodirectional, based on a Neuron Doctrine or single neurotransmitter system. The overemphasis on serotonin (5-HT) is a classical example.

Confined space means that pheromones will be present longer. Stress factors will excite the flies more, making them more prone to intense outputs.
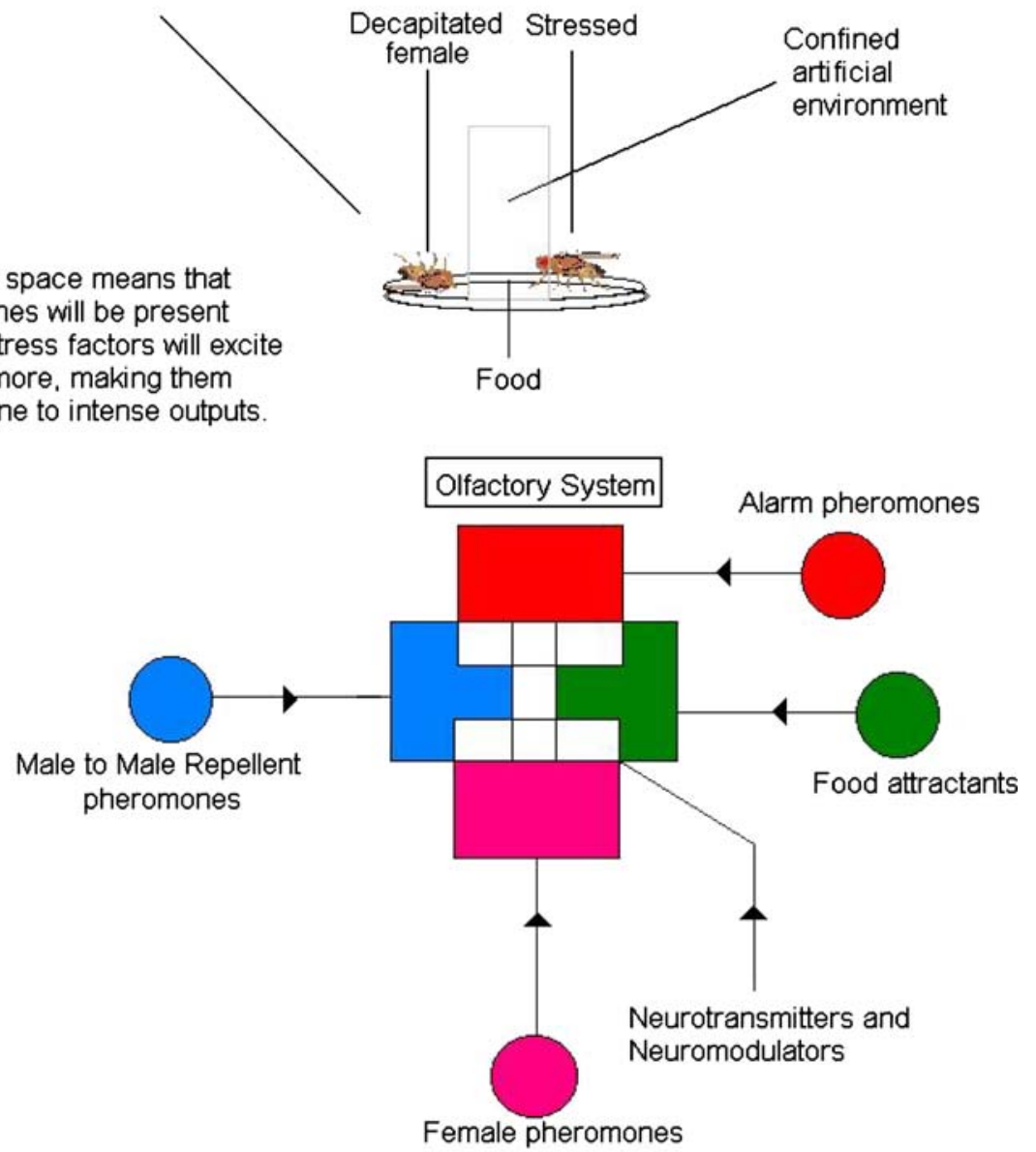

\footnotetext{
Diagram of Systems involved in A Fruit Fly Agonistic Encounter in Laboratory Conditions.
} 
Table 1 Male fruit fly aggression ethogram

\begin{tabular}{lc}
\hline Offensive & Defensive \\
\hline Approach & Walk away \\
Low-level fencing & \\
Wing threat & Defensive W T \\
High-level fencing & Run away, fly \\
Chasing & \\
Lunging & \\
Holding & \\
Boxing & \\
Tussling & \\
\hline
\end{tabular}

(Chen et al. 2002)

\title{
Bridging Insect Agonistic Behaviour and Human Violence
}

\begin{abstract}
Psychopathological violence in criminals and intensely aggressive fruitflies and rodents are studied with novel behavioral, neural biological and genetic approaches that characterize the escalation from adaptive aggression to violence. The fruitless (FruM) gene in octopamine neurons, the estrogen receptor gene, immediate early genes in discrete serotonin and GABA neurons, genes for serotonin receptors subtypes and transporters identify sexually differentiated mechanisms for escalated aggression. Chaired by Klaus A. Miczek and co-chaired by Rose Maria M.de Almeida. San Diego California November 3-7 Symposium Cognition Behavior: Neurobiology of Escalated Aggression and Violence.
\end{abstract}

In recent years the fruit fly, Drosophila melanogaster has become the "comeback kid" in biology, though some might question whether research on this model animal ever peaked. The initial interest in the fruit fly goes back to the days of Thomas Hunt Morgan and his infamous "fly room" the ground zero of the genetics movement. (Brookes 2001) Today the focus is on the "black box"-on an understanding of the genetic and neural bases of behaviours like courtship and aggression. When one discovers a gene and how it is expressed in the fruit fly, then one can proceed to connect this with the various systems involved in behavioural outputs, and later it should be possible to find correlates in humans.

Table 2 Putative pheromones

\begin{tabular}{lll}
\hline Female & Alarm pheromones (?) & Oleic acid Necromone "scent of death" \\
Male-fly & Alarm pheromones (?) & Territorial/Trail Pheromones \\
Both & Kinship Pheromones & \\
\hline
\end{tabular}


Of course the function might not be exactly the same, for example a neurotransmitter/neuromodulator like serotonin has an opposite effect in agonistic behaviour in comparison to human aggressive behaviour where it works as an inhibitor. (Dierick and Greenspan 2006) Currently, based on the research on invertebrate model animals like crayfish, fruit flies, and on vertebrates like golden hamsters, neuroscientists are developing and testing new forms of drugs and genetic manipulations with the view to using these in treating clinical entities like aggressive behaviours and anxiety related disorders.(Nelson R. (Ed.) (2006))

\section{The Angry Fruit Fly}

The charges and tussles of the male Drosophila appear to be forms of aggression.

(Jacobs 1960, p.186)

If Sigmund Freud were to place the tiny fruit fly on the couch, and he were for one moment to forget it was a fly, his approach to the problem of its "head butting" and "lunging" behaviours would include a discussion in terms of the sex or Eros instinct and then secondly in his later work in terms of the Death or Thanatos instinct. (Freud 1948 [1922]) Both theories were developed from a hard-wired physicalist but vitalist theory of energy force (life-force) which also is behind the dominant theory of aggression in the twentieth century, namely Konrad Lorenz's psycho-hydraulic theory (Lorenz 1966), one which was later discounted by Lehrman. (Lehrman 1953) Lorenz had ignored Darwinian theories of evolution and selection, and the discoveries in the nascent field of neuroscience. Of course another problem here is the whole bias of Freudian psychology - aggression and anger is seen as negative. For the fly this is not the case. It is this fact which creates a moral chasm between the model animal and the human. While we might see homologues at the genetic level, some similarities in the neurotransmission, there are differences in the behaviours. Moreover there is also an explanatory gap between the molecular level and the behaviour level even in the fly. Let us ask some basic questions.

1. Is the fruit fly ever angry?

2. Is the fruit fly ever aggressive?

3. Is the fruit fly ever violent?

4. Is the fruit fly ever "intentionally" $1,2,3,4$ ?

The answer to the first is quite simple. The fruit fly lacks the neurobiology hardware and software to be angry. (Panksepp 2005, p. 187). Other mammals do share these (subcortical circuits) and Panksepp makes a strong case for making a "bridge" between them and humans. In the case of second this is true if we consider how aggression is defined by ethologists. It is a component within a larger adaptive behaviour (agonistic) as developed by Scott in 1956. With regard to the question of whether a fly is ever violent, this is easier to answer, because violence is generally thought to be an excessive and inappropriate/immoral/illegal use of force. A fly does 
not have the mens rea to act violently! We can from this describe the differences between invertebrate and vertebrate aggression as follows:

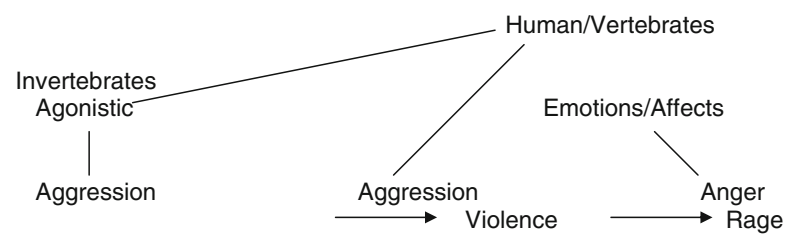

\section{Representation of Agonistic and Aggressive Behaviours in Fruit Flies and Humans}

We can interview a human. This is how we find out how a person feels. Indeed this is the standard approach for the diagnosis of clinical entities in the United States. The number of illnesses has multiplied in the past years. A thousand-fold. However the number of aggressions in animals has remained fairly stable, except in the case of companion animals, where the number of types has gone up in accordance to the "switch" from human applications for anti-depressants to humans. The fruit fly's agonistic behaviour is a much reduced version of its behaviour (for sequence analysis purposes), and only an external version.

\section{Hierarchical Levels of Research into Aggression}

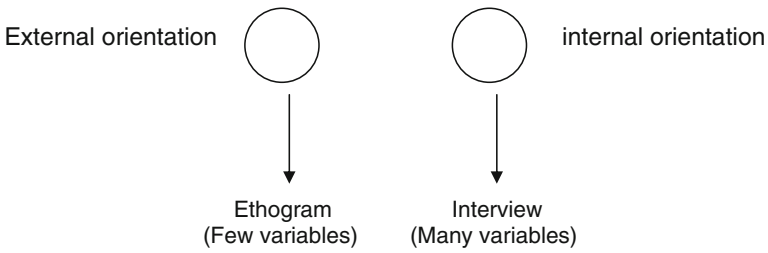

We can not be sure whether the goal-directed behaviour of a fruit fly fits into the modified frustration-aggression models, as we do not know if its simple system has a correlate at this level, we can however hypothesise that emotions evolved and that it is conceivable within its brain and given the presence of several neurobiological elements, it "feels" in a fruit-fly manner, but it does not "feel" anger as we know it. From its approach to an agonistic zone, we know that pheromones play a significant and integrated role in its cognitive behaviour, and this fact should be further researched. As there are millions of species of insects, of which Drosophila melanogaster is but one, we should make an effort to seek more data about their behaviours. With this point in mind, more attention should be paid to the biology and behaviour of the animals as animals and not as systems in the product pipeline of a new "serenics". It is a paradox in this research that the scientists have for years laughed 
at folk psychology, but here we see everything being anthropomorphised: the genome, the genes, the expression, the neurobiological components, and even the behaviour which is described in human martial terms. Below is a diagram of how the fly fits into the scheme of things, in this case dominance aggression/separation anxiety syndrome disorder treatments. (From forthcoming article on companion animals).
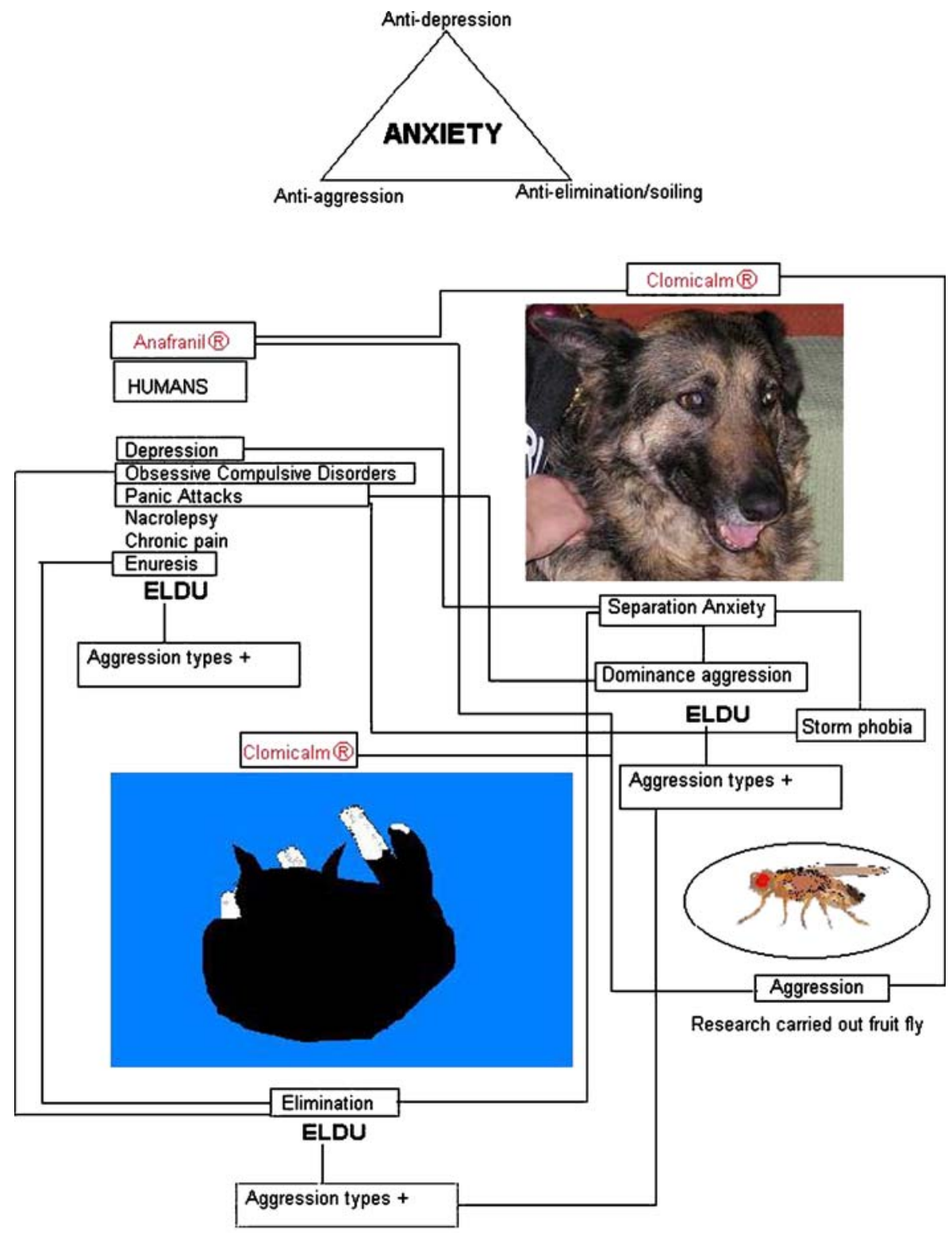

ELDU = Extra-Label Usage 


\section{References}

Brookes, M. (2001). Fly: An experimental life. London: Weidenfeld \& Nicolson.

Chen, S., Lee, A., Yeelin, B., Nina, M., Huber, R., \& Kravitz, E. A. (2002). Fighting Fruit Flies: A Model System for the Study of Aggression. PNAS, 2002(99), 5664-5668.

Dierick, H. A., \& Greenspan, R. J. (2006). Molecular analysis of flies selected for aggressive behavior. Nat Genet Sept, 38(9), 1023-1031.

Ejima, A, \& Griffith L. C. (2007), Measurement of courtship behavior in Drosophila melanogaster CHSH Protocols 2007 doi:10.11.01/pdb.prot 4847.

Ferveur, J-F. (2007), Cuticular hydocarbons: Their evolution and role in drosophila pheromonal communication." Behavior Genetics, Vol. 31 No.3.

Freud, S, (trans. Hubback, C.J.M) (1948), Beyond the pleasure principle. London: Hogarth Press. 1922 Trans.

Guo, J. Z., \& Guo, A. (2005). "Crossmodal interactions between olfactory and visual learning in Drosophila.". Science 8, 309(5732), 307-310.

Jacobs, M. E. (1960). "Influence of Light on Mating of Drosophila melanogaster,". Ecology, 41(1), 182188.

Lehrman, D. S. (1953). A Critique of Konrad Lorenz's Theory of Instinctive Behavior. The Quarterly Review of Biology, 28, 337-362.

Lorenz, K. (1966/1974). On aggression. New York: Harcourt Brace Jovanich. [First Edition 1963].

Moyer, K. E (Ed.) (1976), Physiology of aggression and implications for control: an anthology of readings. N.Y. : Raven Press.

Panksepp, J. (2005). Affective neuroscience. N.Y: Oxford University Press. [PB: 1998].

Paulus, M. P. (2007). Decision-making dysfunctions in psychiatry-altered homeostatic processing. Science Vol, 318, 602-668.

Sturtevant, A. H. (1915). Experiments on sex recognition and the problem of sexual reproduction in Drosophila. J.Anim. Behav, 5, 351-366.

\section{Further Reading}

Adolphs, R., Damasio, A. (2001). The interaction of affect and cognition: a neurobiological perspective. In J. P Forgas (Ed.), pp. 27-49.

Amrein, H. (2004). "Pheromone perception and behavior in Drosophila melanogaster. "Current Opinion in Neurobiology Volume 14 Issue, 4, 435-442.

Baier, A., Wittek, B., \& Brembs, B. (2002). "Drosophila as a new model organism for the neurobiology of aggression. The Journal of Experimental Biology, 205, 1233-1240.

Baron, R. A., \& Richardson, D. R. (1994). Human aggression (2nd ed.). N.Y: Plenum Press.

Baumeister, R. F., Heatherton, T. F., \& Tice, D. M. (1994). Losing control. San Diego: Academic Press.

Biedermann, G. B., \& Davey, V. A. (1993). Social learning in invertebrates. Science, 259, 1627-1628.

Brody, T., \& Cravchik, A. (2000). Drosophila melanogaster G protein-coupled receptors. J. Cell Bio., 150, F83-F88.

Buss, A. H. (1961). The psychology of aggression. New York: Wiley.

Cairns, D. (2000). Essentials of pharmaceutical chemistry. London: Pharmeutical Press.

Cannon, W. B. (1920). Bodily changes in pain, hunger, fear and rage. N.Y.: D. Appleton and Company.

Certel, S. J., Savella, M., Grace, S., Dan, C. F., \& Kravitz, E. A. (2007). "Modulation of Drosophila male behavioral choice. PNAS USA, 104(11), 4706-4711.

Crowell-Davis, S. L., \& Murray, T. (2006). Veterinary psychopharmacology. N.Y.: Wiley.

Eibl-Eibesfeldt, I, (trans. Erich Klinghamner). (1975). Ethology: The biology of behavior. New York: Holt, Reinhart and Winston, Inc.

Farooqui, T. (2007). Octopamine-mediated neuromodulation of insect senses. Neurochem Res., 32, 15111529.

Ferris, C. F., de Vries, G. J. (1997). "Ethological models for examining the neurobiology of aggressive and affiliative behaviours". In Stoff (1997) pp. 255-268.

Forgas, J. P., (Ed.) (2001). Handbook of affect and social cognition. N.Jersey: Lawrence Erlbaum.

Gattellier, L., Nago, T., \& Kanzaki, R. (2004). "Serotonin modulates the response of neuronal populations in the primary olfactory center of the moth olfactory system.". The Journal of Comparative Neurology, 484(2), 168-182. 
Goldstein, A., Carr, E. G., Davidson, I. I., William, S., Wehr, P., et al. (1981). In response to aggression : Methods of control and prosocial alternatives. N.Y.: Pergammon Press.

Gottman, J. M., \& Bakeman, R. (1997). Observing interaction (2nd ed.). Cambridge: Cambridge University Press.

Grimaldi, D., \& Engel, M. S. (2005). Evolution of the insects. New York: Cambridge University Press. Groebel, Jo, Hinde, R A. (Eds.) (1989). Aggression and war. Cambridge: Cambridge University Press.

Hunt, G. J., Wood, K. V., Guzmán-Novoa, E., Lee, H. D., Rothwell, A. P., \& Bonham, C. C. (2003). Discovery of 3-Methl-2-Buten-1-YL Acetate, A New Alarm Component in the Sting Apparatus of Africanized Honeybees. Journal of Chemical Ecology, 29, 453-463.

Huntingford, F., \& Turner, A. (1987). Animal conflict. London \& N.Y.: Chapman and Hall.

Kanzaki, R., Nagasawa, S., \& Shimogawa, I. (2005). "Neural Basis of Odor-Source Searching Behavior in Insect Brain Systems Evaluated with a Mobile Robot.”. Chemical Senses, 30(Supplent I), i285-i286.

Krahé, B. (2001). The social psychology of aggression. Hove, East Sussex: Psychology Press.

Lehner, P. N. (1998). Handbook of ethological methods (2nd ed.). N.Y.: Cambridge University Press. [1976].

Levine, J. D., Fryes, P., Dowse, H. B. E., \& Hall, J. C. (2002). Resettling the circadian clock by social experience in Drosophila melanogaster. Science, 298, 2010-2012.

Lin, H.-H., Lai, J., Sih-Yu, C., An-Lun, C., Yang-Chung, C., \& Chiang, A.-S. (2007). A Map of Olfactory Representation in the Drosophila Mushroom Body. Cell, 128, 1205-1217.

Luscher, K. P. (1959). "Pheronomes" a new term for a class of biologically active substances. Nature, 183, 55-56.

MacLean, P. D. (1980). Sensory and perceptual factors in emotional functions of the triume brain. In Rorty(1980) pp. 9-33. [1970].

Manning, A. (1975). An introduction to animal behaviour (2nd ed.). London: Edward Arnold. $[1972 ; 1967]$

Manuck, S. B. Kaplan, J. R. \& Lotrich, F. E. (2006). Brain serotonin and aggressive dispositions in humans and nonhuman primates. In Nelson Pp. 65-113.

Miczek, K. A., de Almeida, R. M. M., Kravitz, E. A., Rissman, E. F., de Boer, S. F., et al. (2007). "Neurobiology of escalated aggression and violence". Neuroscience, 27(44), 11803-11806.

Morgan, E. D. (2004). Biosynthesis in insects. Cambridge: Royal Society of Chemistry.

Moyer, K. E. (1968). Kinds of aggression and their physiological basis. Comm. Behav.Biol, 2, $65-87$.

Nelson, R. (Ed.) (2006). Biology of aggression. Oxford University Press.

Nielsen, S. P., Yick-Bun chan, R. H., \& Kravitz, E. A. (2004). Gender-selective patterns of aggressive behavior in Drosophila melanogaster. PNAS; 101, 12342-12347.

Ohl, F. (2005). Animal models of anxiety. HEP, 169(459-501), 35-69.

Pain, S. (2007a). "Inner representations and signs in Animals.". In M. Barbieri (Ed.), Introduction tobiosemiotics (pp. 409-455). Dordrect, Netherlands: Springer.

Pain, S. (2007b). "The Ant on the Kitchen Counter. In M. Barbieri (Ed.), Biosemiotic research trends. New York: Nova Science Publishers, Inc.

Ploger, B. J., Yasukawa, K (eds ) (2003). Exploring animal behavior in laboratory and field. San Diego: Academic Press.

Plutchik, R. (1994). The psychology and biology of emotion. N.Y.: HarperCollins.

Ramírez, J. M. (1998). "Aggression”. In G. Greenberg \& M. M. Haraway (Eds.), Comparative psychology: A handbook (pp. 625-634). New York; London: Garland Publishing, Inc.

Renfrew, J. W. (1997). Aggression and its causes. N.Y.: Oxford University Press.

Rorty, A O, (Ed.) (1980). Explaining emotions. Berkeley: University of California Press.

Savarit, F., Sureau, G., Cobb, M., \& Ferveur, J.-F. (1996). Genetic elimination of known pheromones reveals the fundamental chemical basis of mating and isolation in Drosophila. Proc. NatI. Acad. Sci., 96, 9015-9020.

Scott, J. P. (1956). The analysis of social organization in animals. Ecology, 37(2), 213-221.

Silverberg, J., Gray, J. P., (Ed.) (1992). Aggression and peacefulness in humans and other primates. New York: Oxford University Press.

Siwicki, K. K., Riccio, P., Ladewski, L., Marcillac, F., Dartevelle, L., Cross, S. A., et al. (2005). "The role of cuticular pheromones in courtship conditioning of Drosophila males.". Learning and Memory, 12, 636-645.

Smith, D. P. (2007). Odor and Pheromone detection in Drosophila melanogaster. Pflügers Archiv European Journal of Physiology. Vol, 454, 749-758.

Sowa, J. F. (2000). Knowledge representation. Pacific Grove, Ca.: Brooks/Cole.

Spieth, H. T. (1974). Courtship in Drosophila. Annual Review of Entomology, 19, 385-405. 
Stepansky, P. E. (1977). A history of aggression in freud. N.Y.: International Universities Press.

Stockinger, P., Kuitsiani, R., Shay, T., Lásló, D., \& Barry, J. (2005). Neural circuitry that governs Drosophila male courtship behavior. Cell, 121, 795-807.

Stoff, D. M., Breisling, J., Maser, J. D. (Eds.) (1997). Handbook of antisocial behavior. New York: John Wiley.

Strongman, K. T. (2003). The psychology of emotion (5th ed.). Chichester, Sussex: Wiley.

Toch, H. (1972). Violent men. Harmondsworth, Middlesex: Penguin.

Tomkins, L., McRobert, S. P., \& Kaneshiro, K. Y. (1993). Chemical communication in Hawaiian Drosophila. Society for the Study of Evolution, 47, 1407-1419.

Turner, J. H. (1995). On the origins of human emotions. Stanford, Ca.: Standford University Press.

Ueda, A., \& Kidokoro, Y. (2002). Aggressive behaviours of female. Drosophila melanogaster are influenced by their social experience and food resources. "Physiological Entomology. Vol 27 Issue, $1,21-28$.

Vogt, R. (2005). "Molecular basis of pheromone detection in insects". In L. Gibert, K. Latro \& S. Gill (Eds.), Comprehensive insect physiology, biochemistry, pharmacology and molecular biology volume 3 endocrinocrology (pp. 753-804). London: Elsevier.

Volavka, J. (1995). Neurobiology of violence. Washington D.C.: American Psychiatric Press.

Vosshall, L. B. (2007). Nature, 450, 193-197.

Widemo, F., \& Johansson, B. G. (2006). Male-male pheromone signalling in a lekking Drosophila. Proc. Biol. Sci, 273(1587), 713-717.

Wilson, E. O. (2000). Sociobiology: New systems. Harvard, Cambridge Mass.: Belknap Press.

Wyatt, T. D. (2003). Pheromones and animal behaviour. Cambridge: University of Cambridge Press.

Yurkovic, A., Wang, O., Basu, A. C., \& Kravitz, E. A. (2006). Learning and memory associated with aggression in Drosophila melanogaster. PNAS, 107(46), 17519-17524. 